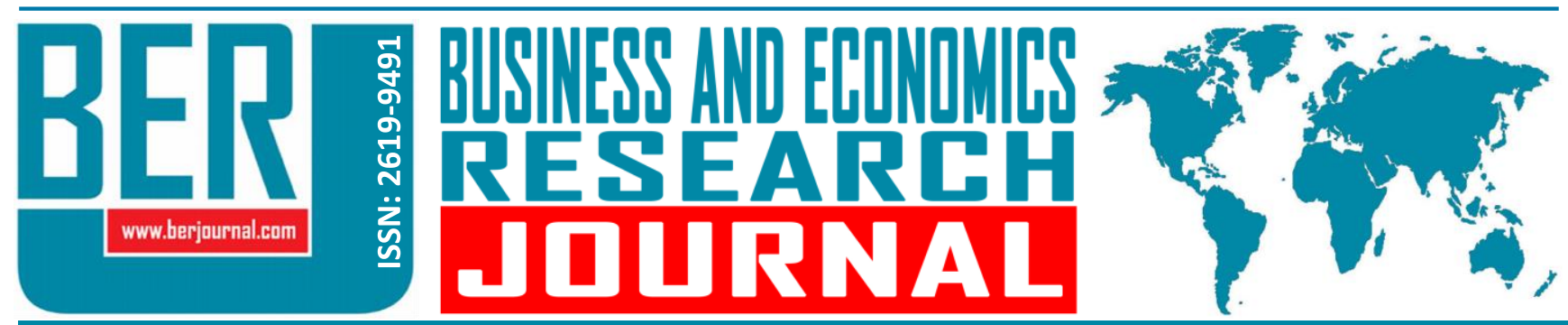

Business and Economics Research Journal Vol. 11, No. 2, 2020, pp. 515-530 doi: 10.20409/berj.2020.264

\title{
Etik Liderlik ve Örgütsel Özdeşleşme Arasındaki İlişki: Kişi Örgüt Uyumunun Aracılık Etkisi ${ }^{1}$
}

\section{Seval Aksoy Kuru}

Öz: Bu araştırmada iş görenlerin etik liderlik algısı ile örgütsel özdeşleşme ve kişi örgüt uyumu arasındaki ilişkinin tespit edilmesi amaçlanmıştır. Araştırma verileri 2018 yılında anket formu kullanarak istanbul'daki kurumsal firmalardaki mavi yakalı çalışanlardan toplanmıştır. Toplanan veriler SPSS ve YEM istatistik programları kullanılarak yorumlanmıştır. Elde edilen sonuçlara göre etik liderlik algısı ve kişi örgüt uyumu arasında, kişi örgüt uyumu ve örgütsel özdeşleşme arasında ayrıca etik liderlik ve örgütsel özdeşleşme arasında anlamlı ilişkiler bulunmuştur. Bunların yanı sıra, araştırmanın temel motivasyonunu oluşturan aracılık etkisi, kişi örgüt uyumunun etik liderlik algısı ve örgütsel özdeşleşme arasında kısmi aracılık etkisi oluşturduğu tespit edilmiştir.

\section{The Relationship between Ethical Leadership and Organizational Identification: Mediating Role of Person- Organization Fit}

Abstract: In this study, it is aimed to determine the relationship between employees" perception of ethical leadership and organizational identification and personorganization fit. The survey data were collected from the blue-collar employees in Istanbul by using a questionnaire form in 2018. The collected data were interpreted using SPSS and SEM statistical programs. According to the results, a significant relationship was found between ethical leadership perception and organizational organization, as well as ethical leadership and organizational identification. In addition, the main motivation of the research is the mediation effect, and it has been determined that the harmony of the person organization fit a partial mediation effect between the ethical leadership perception and organizational identification.

Anahtar Sözcükler: Etik Liderlik, Kişi Örgüt Uyumu, Örgütsel Özdeşleşme

JEL: D23, M10, M12, 015

Geliş

Düzeltme : 19 Temmuz 2019

Kabul : 30 Aralık 2019

Tür : : Araştırma

Keywords: Ethical Leadership, PersonOrganization Fit, Organizational Identification

JEL: D23, M10, M12, O15

Received : 28 May 2019

Revised : 19 July 2019

Accepted : 30 December 2019

Type : Research 


\section{Giriş}

20. yüzyılın ikinci yarısından günümüze kadar liderlik kavramıyla ilgili olarak çok sayıda araştırma yapılmıştır. Yapılan çalışmalar da göz önüne alındığında hali hazırda örgütsel davranış ve yönetim bilimi kapsamında hala üzerinde durulan ve ilgi gösterilen bir kavram olduğu açıktır. Illgi gösterilmesinin yanı sıra genel geçer kabul görmüş olan bir tanımlaması da yoktur. Liderlik kelime kökenine bakıldığında Anglo Sakson kökene dayanmaktadır. Yol ya da yön anlamlarını barındıran liderlik kelime olarak ilk defa Samuel Johnson (1755) tarafından bir sözlükte "kaptan, önder, önden giden kimse" şeklinde tanımlanmıştır (Aykanat ve Gül, 2012). Daha kapsayıcı bir tanımlama olarak ise; amaçların bütünleştirilmesi ve gerçekleştirilmesi, çok yönlü etkileşimselliği ve temelde de bir liderin varlığı ile özdeşleştirme yapıldığı söylenebilir (Şentürk ve Sağnak, 2010). Öte yandan birçok araştırmacı ve bilim insanının da tanımlamaları mevcuttur. Werner'a (1993) göre liderlik, belirlenmiş zaman aralıklarında ve koşullarda örgütsel amaçlara erişmek üzere işgörenleri kendi iradeleriyle çaba göstererek çalışmaya teşvik eden, onlara yol gösteren, deneyimlerini etrafına aktarabilen etkileme sürecidir. Özden'e (2000: 109) göre ise; "büyük değişimlerin yarattığı yeni fırsatları yakalayabilen, belirsizlik ve tehlikelere rağmen bu fırsatları değerlendirerek örgütüne yeni açılımlar getiren kişinin eylemleri" olarak tanımlanmaktadır. Eren (2012: 286) ise liderliği, "liderlik, bir grup insanı belirli amaçlar etrafında toplayabilme ve bu amaçları uğruna o organize grubu harekete geçirebilme yeteneği ve bilgilerinin toplamıdır" olarak ifade etmiştir.

Günümüz iş yaşamında örgütler içinde bulunulan durumlar çerçevesinde gerek yöneticilik gerekse liderliğe ihtiyaç duymaktadırlar. İhtiyaç duyulan liderlik türü de örgüte ve örgütün çözüm arayışına göre çeşitlenmektedir. 21. yüzyılda yönetim dünyasında karşılaşılan ahlaka uygun olmayan düzenlemeler ve davranışlar ile yolsuzluklar hem yönetimde etik anlayışı hem de yönetici konumundaki çalışanların etik nitelikte olması gerekliliğini ortaya koymuştur. Brown vd. (2005) tarafından ifade edilen; kişisel faaliyetlerde ve bireyler arasındaki ilişkiler kapsamında "normatif uygunluk" içinde bir yönetim tarzını ortaya koyan etik liderlik de örgütlerin intiyaç duyduğu bir liderlik olarak karşımıza çıkmaktadır. Örgütteki bireylerin kurdukları karşılıklı iletişimde onları güçlendirerek, ahlaki düşünmeye ve davranmaya sevk eden etik liderlik anlayışı, "iş etiği kapsamında normatif ve sosyal bilimsel temelli bir yaklaşımla" ifade edilmektedir (Brown ve Mitchell, 2010). Etik liderler, benimsediği rol model olma davranışı, yol gösterici ve yardımsever yaklaşımı sonucunda örgütte yer alan işgörenlerde olumlu ve yapıcı yönde değişim ve iyileştirmelere yol açan etik liderler, bireylerin kişi-örgüt uyumuna da katkı sağlamaktadırlar. Çünkü etik liderler örgüt içinde Rubenstein'in de (2001) öne sürdüğü görüşe göre; iki temel anlayışa dayanmaktadır. ilki; etik liderlik, "ne yapılmaması gereken kurallara göre değil, ne yapılması gerektiği ile ilgili kurallarla" açıklanmaktadır, bir diğeri de "etik liderlik, etik davranışları kapsamaktadır" (Akt. Aksoy, 2012:24). Böylece, Harvey'in (2004) etik liderler hem meslektaşları hem de işgörenlerin duygu ve düşüncelerine önem verip ona göre hareket ederler ifadesinden yola çıkarak yukarıda da belirtildiği gibi kişi-örgüt uyumu için bir öncül niteliğindedir. Bunun yanı sıra Tajfel ve Turner'in (1986) Sosyal Kimlik Kuramı'ndan kök alan örgütsel özdeşleşmeyle de sıkı sıkıya bağlıdır. İnsanın sosyal ve psikolojik yönüne önem veren etik liderlik anlayışı bireysel ve örgütsel çıktılara önemli katkılar sunmaktadır. Bahsi geçen kavramları (etik liderlik, kişi örgüt uyumu, örgütsel özdeşleşme) bir bütün olarak ele alan bir araştırmaya rastlanmamış olmasından ötürü yürütülen bu araştırmada İstanbul'daki kurumsal firmalardaki mavi yakalı çalışanlarda etik liderlik algısı, kişi-örgüt uyumu ve örgütsel özdeşleşme arasındaki ilişkinin varlığı sorgulanmaya çalışılmıştır. Bu kapsamda, alan yazında etik liderlik, kişi-örgüt uyumu ve örgütsel özdeşleşme kavramları ve sıralanan bu kavramlar arasındaki ilişkiler de ele alınarak kapsayıcı ve alan yazına katkı sağlayabilecek bir alan araştırması gerçekleştirilmiştir.

\section{Kavramsal Çerçeve}

\subsection{Etik liderlik}

Grek kökenli bir kelime olan etik, "ethos" ve "mores" kelimelerinden türetilmiştir. Sabuncuoğlu'nun (2011) ifadeleriyle etik, doğru ve yanlış türündeki kavramları ele alarak hayatımızda doğru olana ulaşma yollarını sorgulayan düşünsel yapının alt disiplinidir. Bu alt disiplinin örgütsel yansımalarında ise etik kendine liderlik türü olarak da yer bulmaktadır. Etik liderlik olarak alan yazında bilinen liderlik türü; liderin liderlik 
görevini icra ederken etik olan veya etik olmayan davranışlarıyla takipçileri sıfatındaki işgörenleri yapıcı veya yıkıcı yönde etkileyebilen bir konumdadır. Rol model konumunda olan etik liderler, ödül ya da ceza kavramlarını takipçilerine yönelik olarak doğrudan sergilemektedirler. Böylece, örgüt içerisinde çalışanlar tarafından sergilenmesi istenen davranışların pekiştirilmesi ve istenilmeyen davranışların söndürülmesi ve hatta uzun vadede ortadan kaldırılabilmesi için kullanmaktadırlar (Brown ve Trevino, 2006). Örgütlerde etik liderliğin var olması halinde etik lidere düşen dört ana görev mevcuttur. Sırasıyla bakıldığında;

a. Takipçilerine yönelik adetli davranmak,

b. Davranış ve tutumlarıyla takipçileri için birer rol model olmak,

c. İletişimde etkin ve etkili olmak birer gereklilikken;

d. Örgütsel çıktılarda (ürün ve/veya hizmet) uzmanlık sahibi olmak zorunda değildir. Önemli olan, takipçilerine yönelik onların haklarına saygılı olabilmeyi ve daha da önemlisi onların onurlarını zedeleyecek davranışlardan kesinlikle kaçınabilmeyi esas almaktır (Yılmaz, 2005).

Etik liderliğin sahip olduğu görevlerin yanı sıra etiğin temelini oluşturan karakter, dürüstlük ve samimiyete de sahip olmaları da kaçınılmazdır. Dürüstlük ve ahlaki anlamda doğru olanı etik farkındalık esasına göre yapmak etik liderliğin temelidir. İşgörenlerin ilgi, istek ve beklentileriyle uyum gösterecek şekilde onlara yol göstermek ve sonuçta da örgütsel ve toplumsal uyum gerçekleştirebilmek etik liderliğin önemli başka bir özelliğidir. Takipçilerine cesaret vererek onların sorumluluk almalarını sağlayan liderlik türü olan EL bir tür motivasyon kaynă̆ıdır. Tüm bunları yaparken izlediği yolda kullandığı rehber, etik sorumluluk ve yönetim anlayışı normlarından oluşmaktadır (Resick, Hanges, Dickson ve Mitchelson, 2006). Takipçi konumundaki işgörenlerin, üstleri olan yöneticilerinin etik liderlik vasfını sergiliyor olmasından etkilenmektedir. Çünkü onları gözlemleyerek öğrenme eylemini gerçekleştirirler. Böylece takipçilerince izlendiği bilincindeki etik liderler devamlılı̆ı olan etik davranışlar ve eylemler ortaya koyma gayretine sevk olmaktadır (Brown, Trevino ve Harrison, 2005).

\subsection{Kişi-Örgüt Uyumu}

Temelinde insan olan kişi-örgüt uyumu, Kristof'a (1996) göre, kişinin ya da örgütün karşılıklı etkileşiminde taraflardan en az birinin bir diğerinin ihtiyaç ve isteklerini karşılayıp ona tatmin sağlıyor olmasıdır. Bu nedenle de Astakhova'nın (2016) ifadesinde olduğu gibi öncelikle kişinin ihtiyaç ve isteklerini karşılama noktasında kişinin değerleri, kişilik yapısı ve bireysel yetenekleri gibi çeşitli içsel taraflar ve bunlarla benzer nitelikteki unsurlar olan örgütün ve hatta yöneticinin ve/veya liderin değer yargıları, kişilik yapısı, hedef ve iş talepleri gibi birçok dışsal tarafların kıyaslanması olan uyumu bilmek gerekir. Kişi ile örgüt arasında değerler uyumundan bahsebilmek için üç temel şart söz konusudur. Bunlar;

a. Kişi veya örgüt olmak üzere en az birinin ihtiyaç(lar)ının ne(ler) olduğunun diğer tarafça anlaşılıyor olmasıdır.

b. Benzer temel özelliklerin paylaşıııyor olmasıdır.

c. Illk iki şartta söz edilenlerin birlikte sağlanmasıdır (Herrbach ve Mignonac, 2007).

Benzer bir şekilde, kişinin sahip olduğu değer, inanç, norm, beklenti ve amaçlarını çalışmakta olduğu örgüt ve/veya yapmakta olduğu iş arasındaki uyumu kişi-örgüt uyumu olarak ifade edilmektedir (Chatman, 1989; Polatçı ve Cindiloğlu, 2013). Belirtilen bu uyuma bağlı olarak kişi-örgüt uyumu, Schneider'in (1987) kişiörgüt uyumu modeline göre, işgören konumundaki kişilerin örgütlere katılmaları ve süreç içerisinde örgütün birer üyesi olarak devam etmelerinde kendi kişisel değerleriyle örgütün değerleri, kendi amaç ve hedefleriyle örgütün amaç ve hedefleri, benzer şekilde kendi kültürleriyle örgütün kültürel değerlerinin uyumluluğunu belirleyen bir işlev olduğu ifade edilmektedir. 


\section{3. Örgütsel Özdeşleşme}

Örgütsel özdeşleşme alan yazını ele alındığında; örgütle işgören arasında var olan bağı açıklamak ve yönetimin örgütte yer alan üyelerinin ilgisini ve kararlara katılımlarındaki önerilerini artırmayı teşvik etmedeki yararı açıktır (Tompkins ve Cheney, 1985; Ashforth ve Mael, 1989). Tıpkı Sosyal Kimlik Teorisi'nde olduğu gibi bir sınıflandırma örgütsel özdeşleşmede de görülmektedir. Bireyin kendisini bir örgütün üyesi olarak konumlandırmasıyla başladığı varsayılan örgütsel özdeşleşme (Wiesenfeld, Raghuram ve Garud 2001), işgörenin örgütün hemen hemen tüm amaç ve değerlerini kendine mal etmesiyle oluşan bir süreçtir (Eicholtz, 2000). Buchanan'a (1974) göre örgütsel özdeşleşme, bireylerin örgütün amaç ve değerlerine ve bunların gerçekleştirilmesine yönelik olarak kendi rollerine ve örgütüne yönelik taraflı bir duruşun sergilendiği bilişsel ve duygusal bir bağlılıktır.

Örgütsel özdeşleşme için genel geçer tek bir tanımlama yapmak mümkün değildir. Çünkü örgütler de tıpkı insanlar gibi onu etkileyen ve sürekli değişime açık olan çevre koşullarında yer almaktadırlar. Bu nedenle öncelikle özdeşleşme ifadesinin anlamına bakıldığında Türk Dil Kurumu (TDK, 2018) tarafından yapılan tanımlamada "bireyin başka bireylerle kişilik kaynaşması gerçekleştirecek ölçüde onların yaşantılarına ve duygularına katılma süreci" ve "bireyin bu yolla kendi kimliğini tanıması ve tanımlaması süreci" olarak ortaya konulmaya çalışıldı̆ı görülmektedir. Benzer bir anlatımla özdeşleşmeyi Lee (1971: 213-226), "ait olma, sadakat ve paylaşılan özellikler" olarak belirtirken; Freud ise (1938) "başka biriyle duygusal bağ" ifadesiyle belirtmek istemektedir (Akt.: Gautam vd., 2004: 301).

Örgütsel davranış alanında özdeşleşme kavramını ilk kez ele alan Foote'nin ifadesinde işgörenleri isteklendirmenin temel yapı taşı olarak ortaya attığı görülmektedir. Özdeşleşme ifadesi için yapılmaya çalışılan tanımlamalardan hareketle insanın sosyal bir varlık olduğu, iletişim, değişim ve etkileşim içinde olduğu görülmektedir. Bu nedenle de yalnızca özel yaşamında değil iş yaşamında da özdeşleşme kaçınılmaz olmaktadır. Ashforth ve Mael'in (1989) "örgütsel özdeşleşme, araştırmacılar tarafından çalışanların tatmini ile örgütün faydasını etkileyen örgütsel davranış literatürünün kritik yapı taşı olarak kabul görmektedir" ifadelerine göre de bu varsayım desteklenmektedir.

Foote'yi takip eder nitelikte özdeşleşmenin yapısal gelişiminde ikinci araştırmacı Lee olmuştur. Lee'ye (1971) göre örgütsel özdeşleşme, "bireylerin örgütleriyle geniş kişisel özdeşleşmesinin derecesi" olarak tanımlanmaktadır (Akt: Patchen, 1970). Patchen'e göre ise örgütsel özdeşleşme, "katılma, başarma ve işte bağlııktan oluşan bir tasvir" olarak tanımlanmaktadır. Örgütsel özdeşleşme alanında çalışma yapan sosyal psikologlara göre ise özdeşleşme, bireyin çalıştığı örgütle kendini koruyarak mutluluğun sebebinin örgütü olduğunu kabul ettiği bir süreç olarak tanımlamaktadırlar. Dutton, Dukerich ve Harquail'in (1994) çalışmasında örgütsel özdeşleşme, davranışsal bir yaklaşımla ele alınarak; bireyin kendini örgütle özdeşleştiren bir yapı sergilediği ifade edilmektedir. Bir başka deyişle; kendini doğrudan doğruya örgütün kimliğiyle tanımlayan örgüt üyelerinin, örgütün amaçlarını kendilerinin bireysel amaçları gibi kabul ettiklerini, örgüte daha sadık olduklarını ve çalışma arkadaşlarıyla daha uyumlu bir biçimde çalıştıklarını ortaya koymaktadır.

Meal ve Ashforth’a (1995: 317) göre örgütsel özdeşleşme, "örgütle bir olmak algısı ve örgütün başarı ve başarısızıklarını kişinin kendisininmiş gibi sahiplenmesi" olarak tanımlanmaktadır. Tompkins ve Cheney'e (1985) göre ise örgütle yaşanan özdeşleşme bireyin bakış açısına göre şekillenmektedir. Genel anlamda bakıldığında örgütsel özdeşleşme için yapılan birçok tanımlamada birey veya örgüt odaklı olarak sınıflandırma yapıldığı görülmektedir. Bu nedenle de Tompkins ve Cheney (1985) örgütsel özdeşleşmenin gerek ürün gerekse süreç olduğunu ileri sürmektedirler. Kogut ve Zander (1996) örgütsel özdeşleşmeyi, işgörenlerin davranışlarını koordine etmek için kullandıkları düzen ve kurallar bütünü olarak tanımlarken yine Mael ve Ashforth (1992) örgütsel özdeşleşmeyi, işgörenlerin sosyal kimliklerinin bir parçası olup örgütsel kimliğin bir sonucu olarak; Tompkins ve Cheney (1985) de örgüt üyelerinin örgütsel karar önermelerini kabul etmede ve örgütsel fonksiyonlarına göre davranmada, örgütsel davranış türlerini içselleştirip benimsemeye yönelten bir kavram olarak tanımlamaktadırlar. 
Miller, Allen, Casey ve Johnson'a (2000: 631) göre örgütsel özdeşleşme, "i̧̧ görenlere örgütün değerleri ve hedeflerindeki benzerlik sahalarını algılamalarını sağlar, örgütsel amaçları ve faaliyetleri şekillendirme olanağı sağlar, örgütsel hedefleri ve değerleri kabul ederek belirsizliği azaltır" şeklinde yapılan bir tanımlamayla ifade edilmektedir. Örgütüyle özdeşleşen işgörenler, örgüt dışında katılacakları etkinlikler ve kuracakları kişiler arası etkileşim ve iletişimde kendilerini aidiyet duydukları örgütün birer temsilcisi olarak kabul etmektedir. İşleriyle ilgili alacakları önemli kararlarda kurumun menfaatini kendi menfaatlerinden ön planda tutarlar, örgütün değer ve çıkarlarının aleyhine davrananlardan uzaklaşarak bu ve benzeri işgörenlere karşı gereken tavrı kurumu korumak adına doğrudan ortaya koymaktadırlar.

Yapılan tanımlamalardan hareketle örgütsel özdeşleşmenin temelde üç alt unsurdan meydana geldiği anlaşılmaktadır (Tosun, 1981). Sırasıyla bakıldığında;

a. İşgören konumundaki bireyin örgütün amaç ve değerlerine sıkı sıkıya bağlılık hissederek inanması ve bunların tamamını kabul etmesi olduğu görülmektedir. Bu kabul edişle birlikte özdeşleşmenin bireysel ve örgütsel amaçlarının bütünleşmesi olduğu ifade edilebilmektedir (Hall , Schneider ve Nygren, 1970).

b. Bireylerin örgüt içindeki konumlarına göre üstlendikleri rollerini oluşturan tüm gerekleri gönülden ve isteyerek yapmalarıdır. Örgütün amaçlarını tıpkı kendi amaçlarıymış gibi kabul ederek onları yerine getirebilmek adına çalışmak ve performans sergilemek bireyler için adeta bir doyum kaynağıdır. Bahsi geçen doyum düzeyi bireyin örgütüyle yaşadığı özdeşleşmeyle doğru orantılı artış ve azalış göstermektedir.

c. İşgören konumundaki bireylerin üstlendikleri rolleri bir görev bilip bunu sürekli kılmada istekli olmalarıdır. Örgütsel özdeşleşme yaşayan bireyler, mevcut duruma kıyasla maddi ve manevi kazanımları (prim, ücret, terfi, saygınlık, vb.) çok daha yüksek olan koşullar bulsalar dahi örgütlerinden ayrılma davranışı sergilemeyebilmektedir. Bu nedenle de örgütsel özdeşleşme, günümüz çalışma yaşamı ve örgütsel davranış alan yazınında incelenmesi gereken bir unsur olarak ön plana çıkmaktadır.

\subsection{Kavramlar Arasındaki iliş̧kiler ve Hipotezlerin Geliştirilmesi}

Brown'un (2007) ifadesinde de olduğu gibi EL, adalet, doğruluk ve dürüstlük ilkelerini kendine rehber edinmiş ve bunların çizdiği çerçeve içerisinde hareket eden insandır. Bu sayede de etrafının güvenini ve saygısını kazanmaktadır. Bütünleştirici bir gücü de beraberinde getiren güven ve saygı duyguları örgüt içinde karşılaşılacak olan zor durumlarda kenetlenme ve istenilmeyen durumların üstesinden gelebilmede fayda sağlamaktadır. Ahlaki standartlara göre davranışlar sergilen $\mathrm{EL}$, kararları sayesinde işgörenleri olumlu yönde etkileyebilmektedir ve böylece onlara ortak bir vizyon kazandırarak ortak bir amaç etrafında toplayabilmektedir (Demir ve Okan, 2008). Edinilen ortak değerlere bağlı olarak sosyal özdeşleşmenin bir uzantısı olarak kabul edilen işgörenlerin örgüte yönelik benlik duyguları, tutum ve daha da önemlisi davranışlarında örgütsel özdeşleşmede olumlu etkiler oluşturması kaçınılmazdır (İ̧scan, 2006).

Örgüt içerisinde bütünleştirici bir yapısı olan etik liderlik gerek kararlara katılım gerek iletişimde açıklık sağlayan özelliğiyle daha fazla işgörenin örgütün değerlerini benimsemesine temel oluşturmaktadır. Bu durumda oluşan iletişim ve bütünleşme çabasıyla işgörenlerin içsel motivasyonlarında artış sağlanacaktır (Ashforth ve Mael, 1989; Dutton, Dukerich ve Harquail, 1994; Van Knippenberg, 2000; Van Knippenberg ve Sleebos, 2006). Sağlanan motivasyon sayesinde de biz kavramına verilen önem artacak ve bütün için çaba gösterilecektir.

Temelde örgütsel özdeşleşme, işgörenle örgütün bir bütün olmasını savunmaktadır ve işgörenlerde mevcut durumdan daha geniş ölçüde örgüt kimliğinde yer alabilme duygu ve çabasına vurgu yapmaktadır. EL'nin varlığı halinde işgören kendine bir rol model olarak belirlediği yöneticisi sayesinde biz olabilmeye erişebilecek ve bu da işgörenin bütünün bir parçası olabilmesine hizmet edecektir (Rousseau, 1998). Bu bilgiler dahilinde, öne sürülen ilk hipotez şu şekildedir: 
Hipotez 1: Etik liderlik örgütsel özdeşleşmeyi pozitif yönde anlamlı olarak etkiler.

Etik liderin etik ve ahlaki anlamda örnek olma davranışıla etik normlar kazanılmasına öncülük ettiği bilinmektedir (Brown ve Trevino, 2006). Bu sayede de örgütsel değerlerin bütünleştirilmesi ve işgörenlerin değerleriyle örgütün değerleri arasında bir uyum yakalanması ve kişi-örgüt uyumu elde edilmesi mümkündür (Mullane, 2009). Elde edilen kişi-örgüt uyumu, özellikle de işgörenlerin yaptıkları işe yönelik sergiledikleri davranışlarda yapıcı ve olumlu sonuçlara yol açmaktadır (Kılıç, 2010). Olumlu sonuçlardan biri de işgörenin örgütüyle yaşayacağı özdeşleşmedir EL'nin varlığı halinde işgörenle örgütü arasında yaşanan uyumun örgütsel özdeşleşmeye etkisi olumlu yönde olacaktır, tersi bir durumun varlığında ise işgörenin örgütüyle yaşayacağı özdeşleşmede düşüş görülecektir (Valentine, Godkin ve Lucero, 2002). Bu bilgilere bağlı kalarak ikinci hipotez şu şekilde oluşturulmuştur:

Hipotez 2: Etik liderlik kişi-örgüt uyumunu pozitif yönde anlamlı olarak etkiler.

Yapılan araştırmalara bakıldığında (Smidts, Ad, Riel ve Pruyn, 2001; Wiesenfeld, Raghuram ve Garud, 1998) örgütün iletişim gücünün örgütle yaşanacak özdeşleşmeyi etkilediği bilinmektedir. Örgütün kişiyle uyumlu olması halinde işgörende bilgi alamama, belirsizlik yaşama gibi istenmeyen durumları ortadan kaldıracağı böylelikle örgütle yüksek düzeyde özdeşleşme yaşayacağı bilinmektedir (Özcan, 2012). Örgütün amaç, hedef, vizyon ve misyonun işgörenlerin güdülenme düzeylerini etkilemesi bakımından örgütsel özdeşleşmeye etki ettiği düşünülmektedir (Collins ve Porras, 1994; Cornelissen ve Elving, 2003).

Benzer şekilde Boxx, Odom ve Dunn (1991) ve Chatman'in (1991) yaptıkları araştırmalara göre kişiyle örgüt değerlerinin uyum gösterip örtüşmesi de örgütsel özdeşleşmenin oluşmasında etkilidir. Kişi-örgüt uyumunun örgütsel özdeşleşme üzerindeki doğrudan etkisini ortaya koyan çalışmalar da (Saks ve Ashforth, 1997, Edwards ve Cable, 2009: 654-670), Boxx, Odom ve Dunn (1991) ve Chatman'in (1991) çalışmalarını destekler niteliktedir. Kişi-örgüt uyumu ve örgütsel özdeşleşme kavramlarının birbirini etkiliyor olmasından ziyade birbiriyle ilişkisi olduğunu ortaya koyan araştırmaya da Vondey'in (2010) çalışmasında rastlanmaktadır.

Yapılan bu kısa açıklamadan hareketle aşağıda $\mathrm{H}_{3}$ ve $\mathrm{H}_{4}$ hipotezleri sunulmaktadır.

Hipotez 3: Kişi-örgüt uyumu örgütsel özdeşleşmeyi pozitif yönde anlamlı olarak etkiler.

Hipotez 4: Kişi-örgüt uyumu, etik liderlik ile örgütsel özdeşleşme arasındaki ilişkilerde aracılık etkisi oluşturmaktadır.

Tüm bu çalışmalardan elde edilen sonuçlar ve kavramların birbirleri arasındaki ilişkiler dikkate alınarak, kurulan dört hipotez için detaylı analizler yapılarak bu hipotezler doğrulanmaya çalışılmıştır.

\section{Yöntem}

\subsection{Araştırmanın Kavramsal Modeli}

Yapılan bu araştırmada, Karasar'ın (1995) belirttiği gibi; iki ve daha fazla sayıda değişkenin ilişki içinde olma durumunu ve birlikte bir değişimin olup olmamasını tespit etmeye çalışan araştırma modeli olan ilişkisel tarama modeli tercih edilmiştir. Şekil 1'de üç farklı değişkeni konu alan araştırmanın kavramsal modeli gösterilmiştir.

Şekil 1. Araştırmanın Kavramsal Modeli

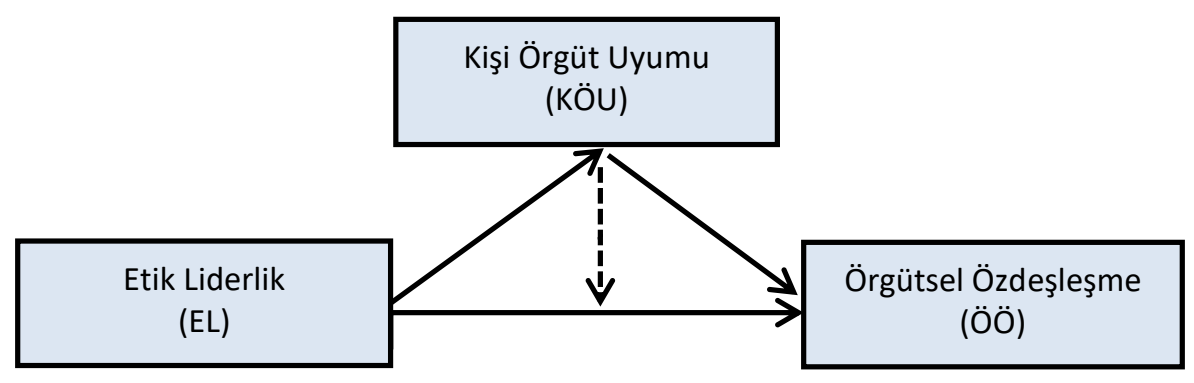




\section{1. Örneklem ve Prosedür}

Bu araştırmada önerilen hipotezleri test edebilmek amacıyla, İstanbul Anadolu yakasında gıda üretim sektöründe faaliyet gösteren vardiyalı çalışma sistemi olup 300'den fazla çalışanı olan büyük ölçekli firmalarda çalışan mavi yakalı işgörenlerden 2018 yılı içerisinde veri toplanmıştır. Araştırmanın mavi yakalı işgörenler üzerinde yapılmışmış olmasının nedeni; lider konumundaki yöneticinin etik liderlik düzeyini ifade edebilmeleri ve çalışılan örgütle olan uyumun ve örgütle yaşanan özdeşleşmeye olası etkisini görebilmektir.

Araştırmanın çalışma evreninden seçilecek örneklem sayısını tespit etmek amacıyla evrenin sayısının belli olması halinde hesaplamada kullanılan eşitlik aşağıda sunulmuştur.

$$
\mathrm{n}=\mathrm{n}_{\mathrm{o}} /\left(1+\mathrm{n}_{\mathrm{o}} / \mathrm{N}\right) \text { ve } \mathrm{n}_{\mathrm{o}}=\left(\mathrm{t}^{2} \mathrm{xs}^{2}\right) / \mathrm{d}^{2}
$$

Formüllerdeki ifadeler, $\mathrm{N}$ : evren büyüklüğü, $\mathrm{n}$ : örneklem büyüklüğü, $\mathrm{t}$ : güven düzeyine karşılık gelen tablo $z$ değeri $(0,05$ için $1,96,0,01$ için 2,58 ve 0,001 için 3,28), s: evren için tahmin edilen standart sapma ve d: kabul sapma toleransını ifade etmektedir (Bartlett, Körtlik ve Higgins, 2001).

$$
\begin{aligned}
& n_{0}=\left(1,96^{2} \times 0,5^{2}\right) / 0,05^{2}=384,16 \\
& n=384,16 /(1+384,16 / 4218)=352,09
\end{aligned}
$$

Araştırma yapılmadan önce pilot çalışma yapılarak anket formundaki ifadelerin katılımcılar tarafından anlaşııırık düzeyi tespit edilmiştir. Anket formları dağıtılmadan önce, araştırmacı tarafından çalışmanın amacı açıklanarak katılımın tamamen gönüllülük esasına dayalı olduğu bütün katılımcılara belirtilmiştir. Araştırmaya katılımın gönüllülük esasına bağlı olmasından ötürü katılımcıların yalnızca demografik bilgilerini kodlamaları talep edilmiştir. Her bir anket formu araştırmacı tarafından katılımcılara kapalı zarflarla bizzat teslim edilmiştir. Anket formalarındaki ifadeler katılımcılar tarafından kodlandıktan sonra, doğrudan araştırmacı yine kapalı zarf içinde teslim edilmiştir. Çalışma kapsamında dağıtılan 500 adet anket formundan 478 tanesi geri dönmüş ve bunlardan da gerek eksik cevaplanmış olmaları gerekse birden fazla işaretleme yapılmış olmasından dolayı 22 anket formu analiz dışına çıkarılmış ve 456 anket formuyla araştırma tamamlanmıştır.

Yazında belirtildiği gibi örneklem sayısının yeterliliği istatistiksel olarak hesaplanmaktadır, 0,95 güven aralığı ve 0,05 örneklem hatasıyla temsil edilebilecek olan evren büyüklüğü aşağıdaki Tablo 1 'de ifade edilmiştir.

Tablo 1. Araştırmanın Evreni ve Örneklemi

\begin{tabular}{|l|c|c|c|c|c|c|c|c|c|c|}
\hline $\begin{array}{l}\text { Evren } \\
\text { Büyüklüğü }\end{array}$ & 100 & 150 & 250 & 500 & 1000 & 5000 & 10000 & 50000 & 100000 & 1000000 \\
\hline $\begin{array}{l}\text { Örneklem } \\
\text { Sayısı }\end{array}$ & 80 & 108 & 152 & 217 & 278 & 357 & 370 & 381 & 383 & 384 \\
\hline
\end{tabular}

Anket formalarının geri dönüş oranı yaklaşık olarak \%96'dır. Tablo değerlerine bağlı kalarak 0,95 güvenilirlik ve 0,05 örneklem hata payıyla elde edilen örneklemin $(n=456)$ evreni temsil ettiği kabul edilmektedir.

Katılımcıların ( $n=456)$ demografik bilgilerine bakıldığında; 338 kişinin erkek $(\% 74,1)$ olduğu görülmektedir. Medeni durumlarının dağııımında ise 267 kişinin $(\% 58,6)$ evli olduğu görülmektedir. Yaş dağılımında ise, 30-39 yaş aralığında 210 kişi, 18-29 yaş aralığında ise 185 çalışan yer almaktadır. Eğitim düzeylerinde de katılımcıların 160'ının $(35,1)$ lise, 154'ünün $(\% 33,8)$ lisans ve $55^{\prime}$ inin $\% 12,1^{\prime}$ 'inin ise önlisans eğitimini tamamlamış olarak bilinmektedir. 456 katılımcının \%38,4'lük kısmı ( $n=175)$ 11-25 işgörenin bir arada çalıştığı birimlerde yer almaktadır. Halihazırda çalışmakta oldukları örgütteki hizmet sürelerine bakıldığında katılımcıların 166'sının $(\% 36,4) 1$ yıl-5 yıl arası ve 133'ünün $(\% 29,2) 5$ yıl üzeri ve 10 yıl arasında yer aldığı tespit edilmiştir. Ayrıca, benzer şekilde 173 katıımcının 1 yıl-5 yıl arası; 132 katılımcının da 5 yıl üzeri ve 10 yıl arası sektör tecrübesine sahip olduğu saptanmıştır. 


\subsection{Kullanılan Ölçekler}

Anket formlarındaki tüm ölçeklerdeki ifadeler beşli Likert tipi ölçekle (1: Kesinlikle Katılmıyorum, ..., 5: Tamamen Katılıyorum) ölçülmüştür. Ölçeklerin güvenilirliği için Cronbach Alpha değeri kullanılmış olup; ölçeklerdeki tüm ifadeler için de ortalama ve standart sapma değerleri hesaplanmıştır. Anket formundaki ifadelerin tümündeki faktörlerin güvenilirlik değerlerinin asgari kabul edilebilir güvenilirlik düzeyi olan 0,70 'in üzerinde olduğu bulgulanmıştır (Nunnally, 1978).

\subsubsection{Etik Liderlik Ölçeği (ELÖ)}

Brown ve arkadaşları (2005) tarafından geliştirilmiş olup Türkçe'ye Tuna, Bircan ve Yeşiltaş (2012) tarafından uyarlanmış ve otel çalışanları için kullanılmış olan, "Kurum müdürüm çalışanların fikirleriyle yakından ilgilenir" ve "Kurum müdürüm adil ve dengeli kararlar verir" gibi ifadelerin de olduğu 10 ifadeden oluşan tek boyutlu ölçek kullanılmıştır.

\subsubsection{Kişi Örgüt Uyumu Ölçeği (KöUö)}

Netemeyer ve arkadaşları (1997) tarafından geliştirilip Türkçe'ye uyarlaması Elçi (2005) tarafından yapılmış olan "Bu kurumun dürüstlük konusundaki değerleri ile benim değerlerim aynıdır" ve "Bu kurumun değerleri ile kişisel değerlerimin uyumlu olduğunu düşünüyorum" gibi ifadelerinde olduğu dört ifadeden oluşan tek boyutlu ölçek kullanılmıştır.

\subsection{3. Örgütsel Özdeşleşme Ölçeği (Ööö)}

Mael ve Ashforth (1992) tarafından geliştirilerek sonrasında Tak ve Aydemir (2004) tarafından Türkçe'ye uyarlaması yapılmış olan ve "Başka biri çalıştığım kurumdan övgüyle bahsettiğinde, bunu şahsıma yönelik yapılmış bir övgü, iltifat olarak kabul ederim" ile "Çalıştığım kurumdan bahsederken; "onlar" yerine "biz" ifadesini kullanırım" gibi ifadelerin de olduğu altı ifadeden oluşan tek boyutlu bir ölçektir.

\subsection{Faktör Analizleri}

Anket formunda er alan ifadeler için yapılan faktör analizi sonucu elde edilen değerler aşağıda yer alan Tablo 2'de verilmiştir.

$\mathrm{Bu}$ çalışmada toplanan veriler üzerinde gerçekleştirilen açıklayıcı ve doğrulayıcı faktör analiz sonuçlarına bağlı olarak analizden hiçbir ifadenin çıkarılmadığı; tek boyutlu etik liderlik, tek boyutlu kişi örgüt uyumu ve yine tek boyutlu örgütsel özdeşleşmeden oluşan üç faktörlü yapının iyi bir uyuma sahip olduğu $\left(x^{2} / s d=2,275(<3), p<0,00, \quad G F I=0,93, \quad C F I=0,96, \quad I F I=0,99, \quad N F I=0,93, R M R=0,04, R M S E A=0,05, \quad A G F I=0,90\right.$ belirtilmektedir.

Tablo 2. Açıklayıcı Faktör Analizi Varimax Döndürme İşlemi Sonrası Yük Değerleri ve Doğrulayıcı Faktör Analizi Sonuçları

\begin{tabular}{ccccc}
\hline Faktör İsmi & Madde No & $\begin{array}{c}\text { Faktör-1 } \\
\text { Yükü }\end{array}$ & $\begin{array}{c}\text { Faktör-2 } \\
\text { Yükü }\end{array}$ & Faktör-3 Yükü \\
\hline \multirow{6}{*}{ Etik Liderlik } & EL10 & 0,809 & - & - \\
& EL8 & 0,804 & - & - \\
& EL3 & 0,788 & - & - \\
& EL9 & 0,788 & - & - \\
& EL2 & 0,781 & - & - \\
& EL5 & 0,775 & - & - \\
& EL6 & 0,767 & - & - \\
& EL7 & 0,767 & - & - \\
\hline
\end{tabular}


Tablo 2. Açıklayıcı Faktör Analizi Varimax Döndürme İşlemi Sonrası Yük Değerleri ve Doğrulayıcı Faktör Analizi Sonuçları (Devam)

\begin{tabular}{|c|c|c|c|c|}
\hline & KÖU3 & - & 0,903 & - \\
\hline Kişi Örgüt & KÖU4 & - & 0,884 & - \\
\hline \multirow[t]{4}{*}{ Uyumu } & KÖU4 & - & 0,865 & - \\
\hline & KÖU1 & - & 0,846 & - \\
\hline & ÖÖ1 & - & - & 0,814 \\
\hline & ÖÖ5 & - & - & 0,807 \\
\hline Örgütsel & ÖÖ3 & - & - & 0,801 \\
\hline \multirow[t]{4}{*}{ Özdeşleşme } & ÖÖ2 & - & - & 0,795 \\
\hline & ÖÖ4 & - & - & 0,771 \\
\hline & ÖÖ6 & - & - & 0,723 \\
\hline & & $\mathrm{EL}$ & KÖU & ÖÖ \\
\hline \multicolumn{2}{|c|}{ Cronbach Alpha $(\alpha)$} & 0,91 & 0,90 & 0,88 \\
\hline \multicolumn{2}{|c|}{ Açıklanan Toplam Varyans } & $\% 55,95$ & $\% 76,51$ & $\% 61,44$ \\
\hline \multicolumn{2}{|c|}{ KMO } & 0,94 & 0,82 & 0,88 \\
\hline \multicolumn{2}{|l|}{ Bartlett's Testi } & $\chi^{2}(45)=2337,47$ & $\chi^{2}(6)=1114,78$ & $\chi^{2}(15)=1228,71$ \\
\hline $\begin{array}{l}\text { DFA Uyum } \\
\text { İndeksleri }\end{array}$ & $\begin{array}{l}\chi^{2} / s d=2,27 \\
R M R=0,04\end{array}$ & $\begin{aligned} \mathrm{GFI} & =0,93, \quad \mathrm{C} \\
\mathrm{RMSEA} & =0,05, \mathrm{AG}\end{aligned}$ & $\begin{array}{l}\mathrm{FI}=0,96, \quad \mathrm{IFI}=0, \\
\mathrm{I}=0,90\end{array}$ & 99, $\quad \mathrm{NFI}=0,93$, \\
\hline
\end{tabular}

\subsection{Hipotezlerin Analizleri}

Çalışmada kullanılan ölçeklerin tanımlayıcı istatistik verileri, Cronbach Alpha güvenilirlik değerleri ve korelasyon katsayıları Tablo 3'te özetlenmiştir.

Tablo 3. Tanımlayıcı İstatistikler, Güvenilirlik ve Korelasyon Değerleri

\begin{tabular}{llllll}
\hline Değişken & Ort. & St. Sap. & EL & ÖÖ & KÖU \\
\hline EL & 3,69 & 0,755 & $0,91^{\alpha}$ & & \\
ÖÖ & 3,61 & 0,861 & $0,50^{* *}$ & $0,88^{\alpha}$ & \\
KÖU & 3,61 & 0,919 & $0,67^{* *}$ & $0,57^{* *}$ & $0,90^{\alpha}$ \\
\hline **Katsayılar 0,01 düzeyinde anlamlıdır. & & & \\
*Katsayılar 0,05 düzeyinde anlamlıdır. & & & \\
$\alpha:$ Cronbach Alpha Güvenilirlik katsayısı, & & \\
EL: Etik Liderlik, ÖÖ: Örgütsel Özdeşleşme, KÖU: Kişi Örgüt Uyumu &
\end{tabular}

Tablo 3'e göre; değişkenler arasındaki ilişkilerin 0,01 düzeyinde anlamlı ilişkiler olduğu görülmektedir.

Etik liderliğin örgütsel özdeşleşme üzerinde olan etkisinde Kişi-örgüt uyumunun aracılık etkisini test edebilmek amacıyla Baron ve Kenny (1986) yaklaşımı kullanılmıştır. Aracılık modelin bu yaklaşımla test edilebilmesi için dört temel şart gerekmektedir. Bu şartlar sırasıyla;

1. Bağımsız değişkenin (etik liderlik) bağımlı değişken (örgütsel özdeşleşme) üzerinde istatistiki düzeyde anlamlı etkisinin olması gerekmektedir.

2. Bağımsız değişkenin (etik liderlik) aracı değişken (kişi-örgüt uyumu) üzerinde anlamlı bir etki oluşturması gerekmektedir.

3. Aracı değişkenin (kişi-örgüt uyumu) bağımlı değişken (örgütsel özdeşleşme) üzerinde oluşturacağı etkinin anlamlı olması gerekmektedir.

4. Aracı değişkenin (kişi-örgüt uyumu) bağımsız değişken (etik liderlik ile beraber modele dâhil edilmesiyle bağımsız değişkenin (etik liderlik) bağımlı değişken (örgütsel özdeşleşme) üzerindeki etkisi azalırken veya tamamen ortadan kalkerken; aracı değişkenin de (kişi-örgüt uyumu) bağımlı 
değişken (örgütsel özdeşleşme) üzerinde anlamlı bir etkisinin olması gerekmektedir (Meydan ve Şeşen, 2011).

Baron ve Kenny (1986) yaklaşımıyla aracılık etkisinin testi için adımlar sırasıyla takip edilmiştir. Öncelikle, bağımsız değişkenin etik liderliğin bağımlı değişken olan örgütsel özdeşleşmedeki etkisinin test edilerek; oluşturulan regresyon yolunun ( $E L \rightarrow O ̈ O ̈$ : Standardize $\beta=0,611$, Standart hata=0,059, $p=0,000$ ) anlamlı olduğu görülmektedir. DFA sonuçları da $\left(\Delta \chi^{2} / s d=1,978, p=.000, G F I=0,951, C F I=0,974,|F|=0,974\right.$, $\mathrm{NFI}=0,949, \mathrm{RMR}=0,045, \mathrm{RMSEA}=0,046)$ elde edilen anlamlılık düzeyini desteklemektedir. İkinci adımda $\mathrm{EL}$ 'nin aracı değişken olan kişi-örgüt uyumu üzerindeki etkisinin varlı̆ı test edilmiştir. Yapılan analizle anlamlı bir ilişkinin ( $E L \rightarrow K O ̈ U$ : Standardize $\beta=0,706$, Standart hata $=0,053, p=0,000$ ) varlığı bulgulanmıştır. DFA sonuçlarıyla da $\left(\Delta \chi^{2} / s d=2,032, p=0,000, \quad G F I=0,956, \quad C F I=0,980, \quad I F I=0,980, \quad N F I=0,962, \quad R M R=0,030\right.$, RMSEA $=0,048$ ) bu ilişki doğrulanmıştır. Üçüncü adımda da aracı değişkenin (kişi-örgüt uyumu) bağımlı değişken (örgütsel özdeşleşme) üzerindeki etkisine bakılmak amacıyla yeni bir regresyon modeli geliştirilmiştir. Bu ilişkinin de (KÖU $\rightarrow$ ÖÖ: Standardize $\beta=0,609$, Standart hata $=0,051, p=0,000$ ) anlamlı olduğu bulgulanmıştır. Bunun yanında, DFA sonuçları da $\left(\Delta \chi^{2} / s d=3,088, p=0,000, G F I=0,959, C F I=0,975, I F I=0,975\right.$, $\mathrm{NFI}=0,963, \mathrm{RMR}=0,033, \mathrm{RMSEA}=0,068$ ) elde edilen ilişkiyi desteklemektedir.

Aracılık etkisinin test edilebilmesi için gereken ilk üç adımın tam ve eksiksiz yerine getirilmesiyle son adım olan etik liderliğin örgütsel özdeşleşme üzerindeki etkisi ve bu etkide kişi-örgüt uyumunun aracılık rolü için bir yol analizi modeli kurulmuştur. Kurulan modele ilişkin sonuç Şekil 1'de gösterilmiştir.

Şekil 1. Aracılık Testi

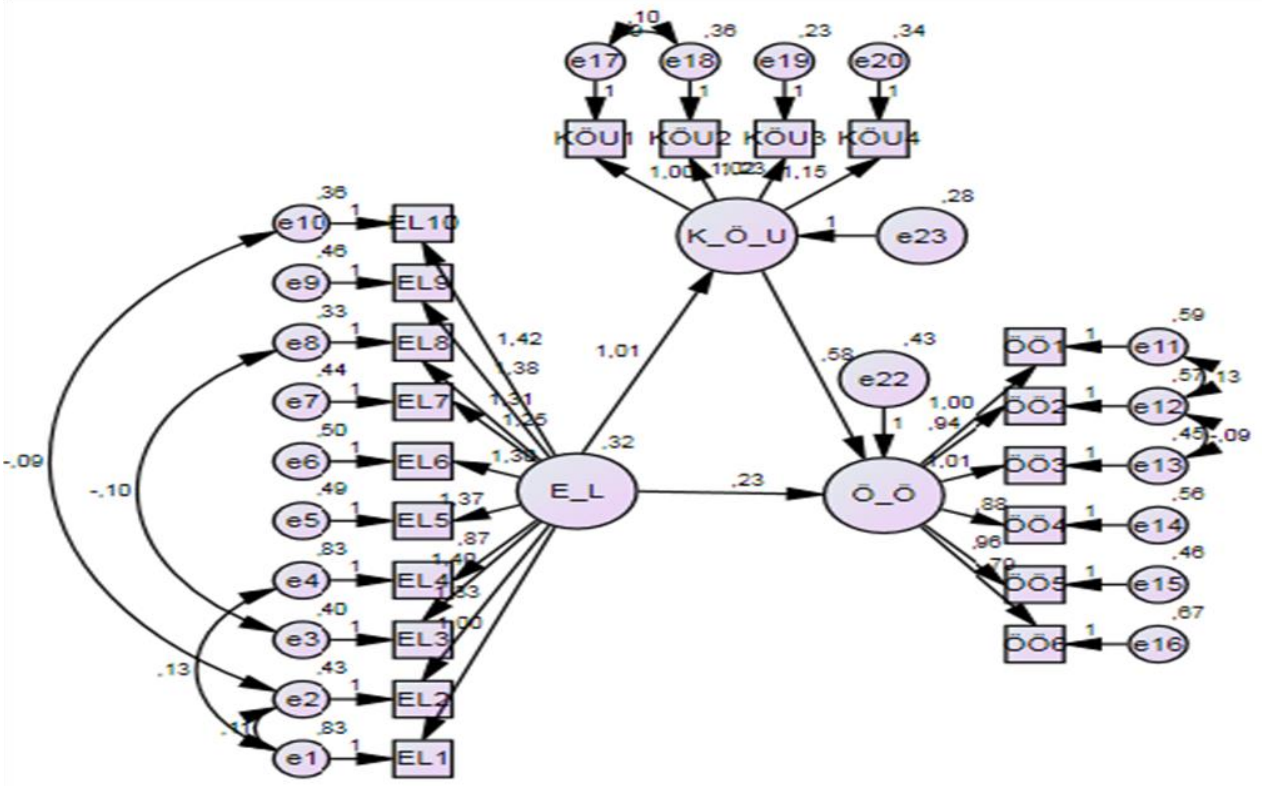

Kurulan aracılık modelin analiz edilmesi sonucunda bağımsız değişken olan EL'nin bağımlı değişken olan örgütsel özdeşleşme üzerindeki anlamlı etkisinin ilk durumdaki etkisine $(\beta=0,611$, Standart hata $=0,059$, $p=0,000$ ) nazaran büyük oranda azaldığı (Standardize $\beta=0,233$, Standart hata $=0,105, p=0,027$ ) bulunmuştur. Ayrıca; kişi-örgüt uyumunun örgütsel özdeşleşme üzerindeki anlamlı etkisinin (Standardize $\beta=0,609$, Standart hata $=0,051, p=0,000$ ) bağımsız değişken olan etik liderlik ile birlikte modele dâhil edilmesinden sonra da (Standardize $\beta=0,584$, Standart hata $=0,084, p=0,000$ ) devam ettiği görülmektedir. Elde edilen bu sonuçlara göre bağımsız değişken olan etik liderlik ile beraber modele dâhil edilen aracı değişkenin (kişi-örgüt uyumu) kısmi aracılık etkisi oluşturduğu bulgulanmıştır. Etik liderlik ile örgütsel özdeşleşme arasındaki ilişkide kişiörgüt uyumunun aracılık etkisinin test edilebilmesi amacıyla oluşturulan regresyon modelinin uyum indeksleri de $\left(\Delta \chi^{2} / s d=2,171, p=0,000, G F I=0,931, C F I=0,964, I F I=0,965, N F I=0,936, R M R=0,042, R M S E A=0,051\right)$ modelin iyi uyum aralığında olduğunu belirterek değişkenin aracılık etkisi oluşturduklarını doğrular niteliktedir. 
Baron ve Kenny'nin (1986) aracılık testi tekniğiyle yapılan analizlerin ardından değişkenler (Etik liderlik ile örgütsel özdeşleşme) arasındaki gerçekleşen değişimin anlamlılığını test edebilmek için "kısmi veya tam aracılığın oluşmasında, bağımsız değişken tarafından açıklanan varyanstaki azalmanın anlamlılığını ölçen bir yöntem (Sobel, 1982)" olan Sobel testi yapılmıştır.

Kişi-örgüt uyumunun, etik liderlik ile örgütsel özdeşleşme arasındaki ilişkide ara değişken etkisini değerlendirmek amacıyla yapılan Sobel testi sonucunda, $t$ istatistiğinin değeri 2,63 olarak hesaplanmış olup; $p$ değerinin de $0,01^{\prime}$ den daha küçük olduğu bulunmuştur. Bu durumda, kişi-örgüt uyumu değişkeninin modele eklenmesiyle birlikte, etik liderlik ile örgütsel özdeşleşme arasındaki ilişkinin anlamlı olarak azaldığı, bir başka ifadeyle kişi-örgüt uyumunun ara değişken etkisinin istatistiksel olarak anlamlı olduğu desteklenmiştir. Dolayısıyla, kişi-örgüt uyumunun modele dâhil edilmesi sonucunda, etik liderlik ile örgütsel özdeşleşme arasındaki ilişkinin anlamlı olarak azaldığı, bir başka ifadeyle kişi-örgüt uyumunun kısmi aracı değişken etkisi oluşturduğu ve bu etkinin de anlamlı olduğu desteklenmiştir.

\section{Bulgular}

Araştırma sonucunda örgütteki işgörenlerin yöneticilerini etik birer lider olarak algılamalarına bakıldığında $\left(E L_{\text {ort.: }}\right.$ 3,69) ortalamanın oldukça üstünde bir değerde seyrettiği rahatlıkla görülmektedir (Bkz: Tablo 3). Bu nedenle de etik bir lider olarak değerlendirilip ifade edilen bir yöneticiyle çalışıyor olmaktan dolayı işgörenlerin elde ettikleri maddi (kaliteli mal ve/veya hizmet) ve manevi (örgütsel aidiyet, rol model edinimi, itaat, vb.) düzeydeki çıktılara olumlu birer yansımanın olacağı düşünülebilir. Öte yandan etik liderliğin var olduğu açıkça ortaya konulan bu araştırmada işgörenlerin kişi-örgüt uyumu elde edebilmelerinde yüksek düzeyde sayılabilecek $\left(0,67^{* *}\right)$ bir ilişkinin olduğu da görülmektedir. Araştırmada elde edilen bu sonuç da yönetici davranışlarının rol model olarak kabul edilerek (Brown ve Trevino, 2006) kişi-örgüt uyumuna erişiminin (Mullane, 2009) ifade edildiği görüşü de destekler durumdadır. Bu durumda araştırmanın hipotezlerinden "Hipotez 2: Etik liderlik kişi-örgüt uyumunu pozitif yönde anlamlı olarak etkiler" hipotezi doğrulanmaktadır.

Etik bir liderin varlığı halinde örgütsel çıktılara olumlu etkisi olduğu tartışılmazdır. Örgütsel özdeşleşme de bu örgütsel çıktılardan biridir. Tablo 3 'teki değerlere $\left(0,50^{* *}\right)$ bakıldığında yönetici konumundaki bireylerin işgörenlerce etik nitelikte algılanması ve bu durumun kabul edilip içselleştirilmesi halinde örgütsel özdeşleşme ile orta düzeyde bir ilişkinin ortaya çıktığı açıktır. Ayrıca bahsi geçen kavramlar arasındaki nedenselliği konu alan analizler sonucu elde edilen değerlere göre de etik liderliğin örgütsel özdeşleşme üzerinde pozitif yönde bir etkisinin $(\beta=0,611$, Standart hata=0,059, $p=0,000)$ olduğu da görülmektedir. Bu durumda araştırmanın hipotezlerinden "Hipotez 1: Etik liderlik örgütsel özdeşleşmeyi pozitif yönde anlamlı olarak etkiler" hipotezi doğrulanmaktadır.

Sosyal kimlik edinimin bir yansıması olan örgütsel özdeşleşmeye erişebilmek için bir işgörenin örgütüyle uyum içerisinde olması kaçınılmazdır. Araştırma sonuçlarına göre de bir işgörenin örgütüyle sağladığı uyum (KÖU ort.: $_{3,61}$ ) ve bunun sağladığı örgütüyle özdeşim (ÖÖ ort.: 3,61 ) kurabilme arasındaki ilişkinin de orta düzeyde olduğu $\left(0,57^{* *}\right)$ ve Vondey'in (2010) çalışmasını da desteklediği görülmektedir (Bkz: Tablo 3). Bu durumda Özcan'ın (2012) araştırmasında olduğu gibi, işgörenlerin örgütlerine dair bilgilere erişim kolaylıkları, alınan kararlara katılım sağlayabilmeleriyle örgütleriyle uyum yakalayabilecekleri; bu sayede de örgütleriyle özdeşleşme yaşayabilecekleri görüşü desteklenmektedir. Örgütün değerlerini benimseyip içselleştirebilen işgörenlerin örgütleriyle özdeşleşmeye sevk olacakları bilincine vurgu yapan araştırmalar da (Boxx vd., 1991; Chatman, 1991; Saks ve Ashforth, 1997; Edwards ve Cable, 2009) olduğu gibi bu araştırma sonuçları da kişi-örgüt uyumunun örgütsel özdeşleşmeye pozitif yönde etki ettiğini doğrulamaktadır (Bkz: Şekil 1). Bu durumda araştırmanın hipotezlerinden "Hipotez 3: Kişi-örgüt uyumu örgütsel özdeşleşmeyi pozitif yönde anlamlı olarak etkiler" hipotezi doğrulanmaktadır.

Ayrıca, aracılık rolünü test etmek için yapılan analizler sonucunda da işgörenlerin örgütleriyle özdeşleşmelerini etik liderlik davranışlarından öte etik liderliğin ve aynı zamanda kişi-örgüt uyumunun varlığıyla birlikte sağlayabileceklerini göstermektedir. Bu sayede de örgütsel özdeşleşmede etik liderliğin kişiörgüt uyumunda bireysel bir motivasyon sağladığı ve böylece Van Knippenberg'in (2000) ifade ettiği gibi örgüt 
içindeki grubun ve/veya grupların değer, amaç ve ilgileriyle işgörenin kendi değerlerinin ortak olarak algılandığı anlaşılmaktadır. Çünkü işgören konumundaki bireyin öncelikle bilişsel bir bağlılık göstermesini öne süren kişi-örgüt uyumu, bireyin örgüt içindeki konumunu ve benlik sınıflandırmasını esas almakta olup bu sayede örgütsel özdeşleşme sağlamanın mümkün olacağını ifade etmekledir (Foreman ve Whetten, 2002: 619; Bellou, Chitiris ve Belleou, 2005). Bu durumda araştırmanın hipotezlerinden sonuncusu olan "Hipotez 4: Kişi-örgüt uyumu, etik liderlik ile örgütsel özdeşleşme arasındaki ilişkilerde aracılık etkisi oluşturmaktadır" hipotezi kısmi aracılık etkisiyle doğrulanmaktadır.

\section{Sonuç, Tartışma ve Öneriler}

Yapılan araştırma sonucunda elde edilen bulgulara bağlı olarak bazı sonuçlar çıkarılmıştır. Schneider'ın da (1987) belirttiği gibi, bireylerin örgüte katılım göstererek kendilerine zamanla örgüt içerisinde birer üye olarak yer edinmeleri gerçekleşir. Bunun için ise kendilerinde aidiyet duygusunun olması gerekir. Schneider'in Uyum Modeli olarak da ifade edilen yapı sayesinde işgörenin örgüte çekilmesi, seçilip örgütteki varlığının sürdürülebilmesi veya örgütten ayrılması döngüsünü ortaya koymaktadır (Schneider, 1987:445). Benzer şekilde Piasentin ve Chapman'in (2006) bakış açısıyla Schneider'in öne sürdüğü döngü işgörenle örgütü arasında yaşanan sosyal etkileşimler neticesinde sosyal kimlik teorisinin özel bir yapısı olan ve bireyin amaçlarının zamanla örgütün amaçlarıyla bütünlük sergilemesi ve uyumlu olması sürecini ifade eden örgütsel özdeşleşmeye imkân sağlamaktadır (Ashforth ve Mael, 1989).

Örgüt içerisinde yönetim uygulamaları, örgütün kültürü ve işleyişi gibi temel yapı taşlarının işgörenle olan uyumunun yüksek olması halinde örgütler için kritik başarı faktörü olan işgörenler örgütte uzun süre faaliyet gösterecektir. İşgörenlerle örgütün paylaşmış olduğu değerler ve hedefler bakımında bir araya gelerek ait olma duygusunu ortaya çıkaracaktır. Bu sayede de kişi örgüt uyumu örgütsel özdeşleşme için önemli bir öncül konumuna gelmektedir (Öğüt ve Kaplan, 2011). Araştırma bulguları da yazında belirtildiği gibi benzer sonuçları ifade etmektedir. Oldukça yüksek bir ortalama değere sahip olan kişi örgüt uyumu değeri (KÖU ort.: $_{3,61)}$ ardından örgütle yaşanacak olan özdeşleşmeyi de beraberinde getirmiştir.

Lider konumundaki bireyin davranışlarının etik çerçevede değerlendirilmesinin ölçümlenmesiyle (ELort: 3,69) örgüt içinde liderin etik bir lider olarak anlamlandırıldı̆ı açıktır. Lider tarafından saptanan amaçlar, konulan hedefler; belirlenen misyon ve vizyona sadık kalmak ve işgörenlerin yüksek düzeyde güdülenmesi sayesinde örgütsel özdeşleşme yaşanması da kaçınılmadır (Collins ve Porras, 1994; Cornelissen ve Elving, 2003). Araştırma bulgularında görülen aralarındaki korelasyon değeri de $(r: 0,50)$ etik liderlik ve örgütsel özdeşleşmenin ilişkili olduğunu ortaya koymaktadır. Etik dışı davranışların olmadığı bir yönetim şeklinin varlığı sayesinde işgörenler kendilerini güvenli bir ortamda hissetmektedir. Bu sayede örgütün düzenli işlemesi, iş sürecinde yaşanabilecek her bir durumda etik değerlerin yönetici tarafından benimsetilerek ortak bir sorumluluğun inşa edilmesi esastır. Bu durumda da etik lider, üstlendiği rol modelliği olumlu ve yapıcı bir şekilde ortaya koyabilir. Sahip olduğu etik değerlerin örgütün değerleriyle bütünleşmesini sağlayarak kişi ve örgüt arasında bir uyum ve ahenk yaratır (Sezgin, 2006). Yaratılan uyuma bağıı olarak da lider tıpkı bir döngüsel güç gibi işgörenlerinin içselleştirmiş oldukları değerler sayesinde alacağı destek ve kabullenilmeyle birlikte aile ve güven ortamı sağlar. Sağlanan güven ortamı da hem bireyin örgütüyle uyumlaşmasını hem de daha kıymetli bir durum olan örgütsel özdeşleşmeyi sağlar. Palalar Alkan ve Arıkboğa (2017) tarafından yapılan çalışmada da benzer görüşler hakimdir.

Benzer nitelikte bir sonuç da Türk ve Akbaba'nın (2018) çalışmasında görülmektedir. Liderin örgüt içinde sergilediği davranışların yapıcı olmasına bağı̆ olarak şekillenen sonuçlar da yapıcı niteliktedir. Liderin doğru sözlü, ahlaklı ve açık sözlü olup her bir işgörenine karşı dürüst bir profil çizebilmesi bireyi örgütüne bağlayacaktır. Bu sayede de işgörenler işlerini sorumluluk ve aidiyet içinde gerçekleştirerek ben olmaktan öte olan biz olma duygu durumuna girerek örgüt yüksek düzeyde özdeşleşme yaşayacaktır. Liderin eşitlikçi tavrı ve yaklaşımıyla kararlara katııı ve yaratıcılıklarını ortaya koyabilmede cesaretli olacak olan işgörenler örgütleriyle uyumu yakalamış olacaktır.

Öte yandan araştırmadaki değişkenlerden farklı bir değişkenle örgütsel özdeşleşme ilişkisinde kişi örgüt uyumunun aracılık etkisine Aksoy, Erdil ve Ertürk (2017) ve Kanbur (2017) tarafından bakılmış olan bir çalışmalarda da tıpkı araştırmamızdaki gibi kişi örgüt uyumunun aracılık etkisi bulgulanmıştır. 
Araştırmaya konu olan bu üç değişkenin bir arada ele alındığı bir çalışmaya yazında rastlanmamış olması nedeniyle yazına önemli katkı sağlanacağı düşüncesi mevcuttur. Bunun yanı sıra, gelecekte araştırma yapacak olan bireyler için bazı öneriler sunulabilir. Araştırma, zaman, emek ve lojistik kısıtlar nedeniyle yalnızca İstanbul'da yürütülmüş olduğu için evrensel bir genellenebilirlik sunmamakla beraber yalnızca tek bir sektör üzerine yoğunlaşmıştır. Bu nedenle, gelecekteki araştırmacılar hem araştırma evrenini çeşitlendirebilir (sektörel ve coğrafi olarak) hem de örneklemi daha geniş tutabilirler. Araştırma üç değişken arasındaki ilişkiyi ele almak üzere modelleştirilmiştir. Araştırmacılar, modellerini oluştururken farkı değişkenlerle yazına katkıyı artırabilirler. Öte yandan teorik temelle oturtulmak şartıyla nitel araştırmayla da zenginleştirilerek karma bir çalışma ortaya konulabilir. Bu sayede yazında kavramlar arası ilişkileri ele alarak genelleme sağlamaya nispeten izin veren içerik analizi ve/veya meta analiz çalışmaları için birer araştırma ortaya konulmuş olacaktır.

Örgüt yöneticileri için sunulabilecek önerilerde ise; en başta araştırmanın bulgularının da ortaya koyduğu üzere etik birer lider olabilmeleridir. Bu sayede işgörenlerinde manevi bir bağ ve uzun vadede olumlu yönde örgütsel sonuçlar (örgütsel vatandaşlık davranışı, örgütsel bağlıık, örgütsel güven, vb.) elde edebilirler. Nitekim kendilerine bir rehber niteliği taşıyan güvenilebilir bir yöneticinin yolundan yürüyebilen işgörenler kendilerini örgütlerine ait hissederek adayabilecektir. Ayrıca, kararlara katılım ve çok sesliliğe imkân veren etik liderlik anlayışının olduğu bir yönetici çalışanları için olumlu bir algı yaratacaktır.

\section{Beyan ve Açıklamalar (Disclosure Statements)}

1. Bu çalışmanın yazarı, araştırma ve yayın etiği ilkelerine uyduğunu kabul etmektedir (The author of this article is admitted that she complied with the principles of research and publication ethics).

2. Yazar tarafından herhangi bir çıkar çatışması beyan edilmemiştir (No potential conflict of interest was reported by the author).

3. Bu çalışma, intihal tarama programı kullanılarak intihal taramasından geçirilmiştir (This article was screened for potential plagiarism using a plagiarism screening program).

\section{Son Notlar}

1. Bu çalışma, 7. Ulusal Örgütsel Davranış Kongresinde sunulmuş olan bildiri metnin geliş̧tirilmiş, düzenlenmiş ve güncellenmiş halidir.

\section{Kaynaklar}

Aksoy, S. (2012). Etik liderlik ve örgütsel vatandaşlık davranışlarının örgütsel performansa etkisi üzerine bir araştırma. Gebze Yüksek Teknoloji Enstitüsü, Yüksek Lisans Tezi, Gebze, Kocaeli.

Aksoy, S., Erdil, O., \& Ertürk, A. (2017). Etik iklim: Kavramsal gelişimi, bireysel ve örgütsel etkileri. Doğuş Üniversitesi Dergisi, 18(2), 133-151.

Ashforth, B. E., \& Mael, F. (1989). Social identity theory and the organization. Academy of Management Review, 14(1), 20-39.

Astakhova, M. N. (2016). Explaining the effects of perceived person-supervisor fit and person-organization fit on organizational commitment in the US and Japan. Journal of Business Research, 69(2), 956-963.

Aykanat, Z., \& Gül, H. (2012). Karizmatik liderlik ve örgüt kültürü ilişkisi üzerine bir araştırma. Atatürk Üniversitesi Sosyal Bilimler Enstitüsü Dergisi, 16(1), 17-36.

Baron, M., \& Kenny, D. A. (1986). The moderator-mediator variable disrinction in social psychological research: Conceptual, strategical statistical conderations. Journal of Personality and Social Psychology, 51(6), 1173-1182.

Bartlett, J. E., Körtlik, J. W., \& Higgins, C. C. (2001). Organizational research: Determining appropriate sample size in survey research. Information Technology, Learning and Performance Journal, 19(1), 43-50. 
Bellou, V., Chitiris, L., \& Belleou, A. (2005). The impact of organizational identification and self- esteem on organizational citizenship behavior: The case of Greek public hospitals. Operational Research An International Journal, 5(2), 305318.

Boxx, W., Odom, R. Y., \& Dunn, M. G. (1991). Organizational values and value congruence and their impact on satisfaction, commitment, and cohesion: An empirical examination within the public sector. Public Personnel Management, 20(1), 195-205.

Brown, M., Trevino, L. K., \& Harrison, D. A. (2005). Ethical leadership: A social learning perspective for construct development and testing. Organizational Behavior and Human Decision Processes, 97,119-120.

Brown, M., \& Trevino, L. (2006). Ethical leadership: A review and future directions. The Leadership Quarterly, 17, 596598.

Brown, M. E. (2007). Misconceptions of ethical leadership: How to avoid potential pitfalls. Organizational Dynamics, 36(2), 140- 155 .

Brown, M. E., \& Mitchell, M. S. (2010). Ethical and unethical leadership: Exploring new avenues for future research. Business Ethics Quarterly, 20(4), 583-616.

Buchanan, B. (1974). Building organizational commitment: The socialization of managers in work organizations. Administrative Science Quarterly, 19(4), 533-546.

Chatman, J. A. (1989). Improving interactional organizational research: A model of person-organization fit. Academy of Management Review, 14(3), 333-349.

Chatman, J. A. (1991). Matching people and organizations: Selections and socialization in public accounting firms. Administrative Science Quarterly, 36(3), 459-484.

Collins, J., \& Porras, J. I. (1994). Build to last. New York: Harper Collins.

Cornelissen, J. P., \& Elving, W. J. L. (2003). Managing corporate identity: An integrative framework of dimensions and determinants. Corporate Communications: An International Journal, 8(2), 114-120.

Demir, H., \& Okan, T. (2008). Etkileşimsel ve dönüşümsel liderlik: Bir ölçek geliştirme denemesi. Istanbul iktisadı Enstitüsü Dergisi, 61, 72-90.

Dutton, J. E., Dukerich, J. M., \& Harquail, C. V. (1994). Organizational images and member identification. Administrative Science Quarterly, 39(2), 239-263.

Edwards, J. R., \& Cable, D.M. (2009). The value of value congruence. Journal of Applied Psychology, 94(3), $654-677$.

Eicholtz, M. M. (2000). Organizational identification as a negotiated relationship: The dialectics of members' dialogue. Ohio University, Unpublished PhD. Thesis.

Elçi, M. (2005). Örgütlerde etik iklimin personelin vatandaşlık davranışlarına etkileri. Gebze Yüksek Teknoloji Enstitüsü Sosyal Bilimler Enstitüsü, Doktora Tezi, Gebze, Kocaeli.

Eren E. (2012). Örgütsel davranış ve yönetim psikolojisi (13. Baskı). Beta Yayınları.

Foote, N. (1951). Identification as the basis for a theory of motivation. American Sociological Review, 16(1), 14-21.

Foreman, P., \& Whetten, D. A. (2002). Members identification with multiple-identity organizations. Organization Science, 13(6), 618- 635.

Freud, S. (1938). Abriss der psychoanalyse internat. Zschr Psychonal Image, 25, 7-6.

Gautam, T., Van Dick, R., \& Wagner, U. (2004). Organizational identification and organizational commitment: Distinct aspects of two related concepts. Asian Journal of Social Psychology, 7(3), 301-315.

Hall, D. T., Schneider, B., \& Nygren, H. T. (1970). Personal factors in organizational identification. Administrative Science Quarterly, 15, 176-190.

Harvey, E. (2004). Liderlik ve etik. Executive Excellence, 8(87), 13-27.

Herrbach, O., \& Mignonac, K. (2007). Is ethical profit really related to individual outcomes? Business\&Society, 46(3), 304-330.

İşcan, Ö. F. (2006). Dönüştürücü/etkileşimci liderlik algısı ve örgütsel özdeşleşme ilişkisinde bireysel farklılıkların rolü. Akdeniz Üniversitesi i.i.B.F. Dergisi, 11, 160-177.

Kanbur, E. (2017). Psikolojik güçlendirme ve örgütsel özdeşleşme arasında birey-örgüt uyumunun aracı rolü. Uluslararası Sosyal ve Eğitim Bilimleri Dergisi, 4(7), 63-82.

Kılıç, K. C. (2010). Bireysel ve örgütsel değerler arasındaki uyumun çalışanların iş davranışlarına etkileri üzerine ampirik bir çalışma. Çukurova Üniversitesi Sosyal Bilimler Enstitüsü Dergisi, 19(1), 20- 35. 
Kogut B., \& Zander, U. (1996). What firms do? Coordination, identity and learning. Wharton School, University of Pennsylvania, Philadelphia and Stochholm School of Economics, Stockholm, Sweden.

Kristof, A. L. (1996). Person-organization fit: An integrative review of its conceptualizations, measurement, and implications. Personnel Psychology, 49, 1- 49.

Lee, S. M. (1971). An empirical analysis of organizational identification, The Academy of Management Journal, 14(2), 213-226.

Mael, F. A., \& Ashforth, B. E. (1992). Alumni and their alma mater: A partial test of the reformulated model of organizational identification. Journal of Organizational Behaviour, 13(2), 103- 123.

Meydan, C. H., \& Şeşen, H. (2011). Yapısal eşitlik modellemesi AMOS uygulamaları (1.Baskı). Ankara: Detay Yayıncılık.

Miller, V. D., Allen, M. Casey, M. K., \& Johnson, J.R. (2000). Reconsidering the organizational identification questionnaire. Management Communication Quarterly, 13(4), 626-658.

Mullane, S. (2009). The Johnson A. Edosomwan Leadership Institute University of Miami, White Paper Series, 2. http://www.bus.miami.edu/_assets/files/executive- education/leadership-institute/ethics-and-leadership.pdf (Erişim Tarihi: 15.01.2019).

Netemeyer, R. G., Boles, J. S., McKee, D. O., \& McMurrian, R. (1997). An investigation into the antecedents of organizational citizenship behaviors in a personal selling context. Journal of Marketing, 61(3), 85-98.

Nunnally, J. (1978), Psychometric methods (2 ${ }^{\text {nd }}$ Ed.). New York. McGraw-Hill.

Öğüt, A., \& Kaplan, M. (2011). Otel işletmelerinde etiksel iklim algılamaları ile örgütsel bağlılık arasındaki ilişkinin analizi: Kapadokya örneği. Dumlupınar Üniversitesi Sosyal Bilimler Dergisi, 30, 191-203.

Özcan, H. U. (2012). Birey-örgüt değerleri arasındaki uyumun örgütle özdeşleşme ile ilişkisi. Türk Psikoloji Yazıları, 15(29), 25-39.

Özden, Y. (2000). Eğitimde dönüşüm: Eğitimde yeni değerler. Ankara: Pegem Yayınları.

Palalar Alkan, D., \& Arıkboğa, F. Ş. (2017). Etik liderlik ve örgütsel vatandaşlık davranışı ilişkisinde örgütsel özdeşleşmenin aracılık etkisi ve bir uygulama. Yönetim ve Ekonomi, 24(2), 349-369.

Patchen, M. (1970). Participation, achievement, and involvement on the job. Englewood Cliffs, NJ: Prentice Hall.

Piasentin, K. A., \& Chapman, D. S. (2006). Subjective person-organization fit: Bridging the gap between conceptualization and measurement. Journal of Vocational Behavior, 69, 202-221.

Polatçı, S., \& Cindiloğlu, M. (2013). Kişi-örgüt uyumunun örgütsel vatandaşlık davranışına etkisi: duygusal bağlılığın aracılık rolü. Süleyman Demirel Üniversitesi Iktisadi ve Idari Bilimler Fakültesi Dergisi, 18(3), 299-318.

Resick, C. J., Hanges, P. J., Dickson, M. W., \& Mitchelson, J. K. (2006). A cross-cultural examination of the endorsement of ethical leadership. Journal of Business Ethics, 63(4), 345-359.

Rousseau, D. M. (1998). Why workers still identify with organizations? Journal of Organizational Behavior, 19(3), 217233.

Sabuncuoğlu, Z. (2011). İşletme etiği (1. Baskı). İstanbul: Beta Yayınevi.

Saks, A. M., \& Ashforth, B. E. (1997). A longitudinal investigation of the relationship between job information sources, applicant perceptions of fit and work outcomes. Personnel Psychology, 50(2), 395-426.

Schneider, B. (1987). The people make the place. Personnel Psychology, 40(1), 437-453.

Smidts, A., Ad, T. H., Riel, C. B. M., \& Pruyn, A. T. H. (2001). The impact of employee communication and perceived external prestige on organizational identification. Academy of Management Journal, 44(5), 1051-1062.

Şentürk, C., \& Sağnak, M. (2010). İlköğretim okulu müdürlerinin liderlik davranışları ile okul iklimi arasındaki ilişki. Türk Eğitim Bilimleri Dergisi, 10(1), 29-47.

Tajfel, H., \& Turner, J. C. (1986). The social identity theory of intergroup behavior. In S. Worchel \& W. G. Austin (Ed.), Psychology of intergroup relations. Chicago, IL, Nelson, 7-24.

Tak, B., \& Aydemir, B.A. (2004). Örgütsel özdeşleşme üzerine iki görgül çalışma. 12. Ulusal Yönetim ve Organizasyon Kongresi, Uludağ Üniversitesi, Bursa.

Türk Dil Kurumu (TDK), (2016). http://www.tdk.gov.tr/index.php?option=com_gts\&arama=gts\&guid=TDK.GTS.5a462c66cb0785.09487681 (Erişim tarihi: 17.12.2018). 
Türk, M., \& Akbaba, M. (2018). Etik liderlik algısının psikolojik kontrat ihlali ve örgütsel özdeşleşme üzerine etkisi: Antalya ilindeki beş yıldızlı konaklama işletmeleri üzerine bir araştırma. Türk \& Islam Dünyası Sosyal Araştırmalar Dergisi, 5(16), 382-407.

Tompkins, P. K., \& Cheney, G. (1985). Communication and unobtrusive control in contemporary organizations. R.D. McPhee \& P.K. Tompkins (Eds), Organizational communication: Traditional themes and new directions. Beverly Hills, CA: Sage, 179-210.

Tosun, M. (1981). Örgütsel etkililik. Ankara: Türkiye ve Ortadoğu Amme İdaresi Enstitüsü Yayınları, 196.

Tuna, M., Bircan, H., \& Yeşiltaş, M. (2012). Etik liderlik ölçeğinin geçerlilik ve güvenilirlik çalışması: Antalya örneği. Atatürk Üniversitesi iiBF Dergisi, 26(2), 143-156.

Valentine, S., Godkin, L., \& Lucero, M. (2002). Ethical context, organizational commitment, and person-organization fit. Journal of Business Ethics, 41, 349- 360.

Van Knippenberg, D. (2000). Work motivation and performance: A social identity perspective. Applied Psychology: An International Review, 49, 357- 371.

Van Knippenberg, D., \& Sleebos A. E. (2006). Organizational identification versus organizational commitment: Selfdefinition, social exchange, and job attitudes. Journal of Organizational Behavior, 27, 571-584.

Vondey, M. (2010). The relationship among servant leadership, organizational citizenship behavior, person-organization fit and organizational identification. International Journal of Leadership Studies, 6(1) ,3-27.

Werner, i. (1993). Liderlik ve yönetim. İstanbul: Rota Yayınları.

Wiesenfeld, B. M., Raghuram. S., \& Garud, R. (1998). Communication patterns as determinants of organizational identification in a virtual organization. Journal of Computer Mediated Communication, 3(4), 777-790.

Yılmaz, E. (2005). Ahlâk, toplum yapısının bir parçası olarak etik ve liderlik, öğretmenin dünyası. Odun Pazarı Belediyesi Yayınları Eğitim Dizisi-3, Ankara: Mikro Yayıncılık. 